\title{
PENGEMBANGAN KETERAMPILAN MEMBERI PADA PESERTA DIDIK: SEBUAH KAJIAN UNTUK MEMPERLUAS KAPASITAS KEGIATAN PEMBELAJARAN
}

\section{DEVELOPMENT OF GIVING SKILL IN STUDENTS: A STUDY TO ENLARGE THE CAPACITY OF TEACHING AND LEARNING ACTIVITY}

\author{
Irene Nusanti \\ PPPPTK Seni dan Budaya Yogyakarta \\ Jalan Kaliurang Km 12.5, Klidon, Sukoharjo, Ngaglik, Sleman, Yogyakarta \\ e-mail: nuss.peace@yahoo.com
}

Naskah diterima tanggal: 14/11/2014, Direvisi akhir tanggal: 11/08/2015, disetujui tanggal: 13/08/2015

\begin{abstract}
The purpose of this article is to describe the capacity of teaching and learning activity in cultivating the concept of giving and providing students with an understanding of a lifestyle of giving and in enabling students to practice skills of giving and develop a lifestyle of giving. This study of skills in giving was conducted by studying a number of teaching and learning theories as well as theories of self-development and character building through habituation to improve students' quality of life. The study of theories on teaching and learning activity revealed that through giving students learn how to improve their quality of life. The study of theories on self-development and character building revealed that what a student does every day in teaching and learning activities will form them into givers, not takers. The conclusion of this study is that skills in giving can be cultivated and practiced, thus enabling students to have a lifestyle of giving.
\end{abstract}

Keywords: giving skill, capacity of learning activities, lifestyle of giving

Abstrak: Penulisan artikel ini bertujuan untuk memberikan gambaran tentang pengembangan kapasitas kegiatan pembelajaran dengan menanamkan konsep keterampilan memberi agar peserta didik memahami gaya hidup memberi dan dengan mempraktekkan keterampilan memberi agar peserta didik memiliki gaya hidup memberi. Pengkajian terhadap keterampilan memberi dilaksanakan dengan mempelajari berbagai referensi tentang teori-teori belajar dan juga hal-hal yang terkait dengan pengembangan diri dan pembentukan karakter. Kajian terhadap referensi tentang teori belajar menunjukkan bahwa melalui memberi, peserta didik belajar meningkatkan kualitas hidup. Kajian terhadap referensi tentang pengembangan diri dan pembentukan karakter menunjukkan bahwa apa yang dilakukan sehari-hari dalam kegiatan belajar mengajar akan membentuk peserta didik menjadi seorang giver, bukan seorang taker. Berdasarkan kajian tersebut disimpulkan bahwa keterampilan memberi dapat digunakan untuk mengembangkan kapasitas kegiatan pembelajaran dengan menanamkan pada peserta didik dan mempraktekkannya sehingga peserta didik memiliki gaya hidup memberi.

Kata kunci: keterampilan memberi, kapasitas kegiatan pembelajaran, gaya hidup memberi 


\section{PENDAHULUAN}

Pemberitaan di berbagai media tentang berbagai hal negatif seperti tawuran pelajar, pelajar terlibat narkoba, membuat pemerintah prihatin atas moral bangsa. Salah satu wujud keprihatinan adalah dengan memberikan perhatian terhadap dunia pendidikan melalui Kementerian Pendidikan dan Kebudayaan dengan dicanangkannya Kurikulum 2013 (Kementerian Pendidikan dan Kebudayaan, 2013). Beberapa alasan kurikulum 2006 dikembangkan sehingga memunculkan kurikulum 2013, yaitu: 1) adanya tantangan masa depan seperti masalah lingkungan hidup, kemajuan teknologi informasi, pergeseran kekuatan ekonomi dunia; 2) fenomena negatif yang mengemuka seperti: perkelahian pelajar, narkoba, kecurangan dalam ujian; 3) kompetensi masa depan, seperti: kemampuan berkomunikasi, kemampuan berpikir jernih dan kritis; dan 4) persepsi masyarakat, seperti: terlalu menitikberatkan pada aspek kogntif, kurang bermuatan karakter.

Munculnya beberapa fenomena negatif di kalangan peserta didik adalah karena sikap kurang peduli, baik pada diri sendiri maupun pada orang lain. Untuk itu perlu ditanamkan sikap peduli dalam pembelajaran. Sikap peduli merupakan soft skill yang tidak hanya dibutuhkan pada saat sekolah, tetapi juga pada saat sudah bekerja. Menurut penelitian National Association of Colleges and Employers (NACE) umumnya pengguna tenaga kerja membutuhkan keahlian kerja berupa $82 \%$ soft skills and selebihnya $18 \%$ hard skills (Sindo, 2011). Perusahaan tidak ingin mempekerjakan karyawan yang tidak peduli atau tidak mau dididik. Terkait dengan hal tersebut, dunia pendidikan dipilih karena dianggap sebagai tempat di mana generasi muda mendapatkan bekal untuk mempersiapkan masa depannya, sekaligus masa depan bangsa. Sebagai generasi penerus, sikap peduli harus dimiliki, supaya fenomena negatif tidak merajalela. Dengan demikian, masyarakat Indonesia akan lebih aman dan sejahtera. Salah satu upaya yang bisa dilakukan supaya generasi penerus memiliki sikap peduli adalah dengan menanamkan mind set sebagai seorang pemberi (a giver) dan mengajarkan keterampilan memberi tersebut kepada peserta didik. Meyer (2010b) mengatakan bahwa mind set mengarahkan tindakan. Jika memiliki mind set seorang pemberi, diharapkan tindakan memberi akan banyak dilakukan bagi orang lain. Mengajarkan konsep memberi tidak selalu harus dikaitkan dengan uang. Banyak hal bisa diberikan oleh seseorang kepada orang lain selain uang, misalnya: memberikan perhatian, memberikan pertolongan, dan sebagainya. Memberi yang dimaksud di sini adalah memberi yang sifatnya tulus, bukan memberi dengan maksud untuk dipuji orang, atau supaya mendapatkan sesuatu yang diinginkan. Memberi juga dapat meningkatkan kualitas hidup (Maxwell, 2009). Dengan mengembangkan keterampilan memberi, keluarga, masyarakat dan diri sendiri juga akan diuntungkan (Jamal dan Mc.Kinnon, 2009). Berdasarkan segi positif dari beberapa referensi tersebut, maka keterampilan memberi dipilih menjadi terobosan yang diharapkan dapat mengantisipasi berbagai fenomena negatif di atas. Keterampilan memberi menjadi salah satu keterampilan yang harus dimiliki oleh peserta didik. Untuk itu, kegiatan pembelajaran seharihari yang merupakan inti dari pembelajaran di sekolah perlu menjadi waktu untuk memperkenalkan konsep memberi karena beberapa hal, yaitu: 1) kegiatan pembelajaran merupakan kegiatan yang dapat membelajarkan banyak hal kepada peserta didik, termasuk keterampilan memberi 2) kegiatan pembelajaran merupakan waktu bagi peserta didik untuk setiap hari mempraktekkan semua yang diajarkan; dan 3) kegiatan pembelajaran merupakan waktu yang dapat mengubah peserta didik karena berlangsung terus menerus setiap hari (Maxwell, 2014a).

Berdasarkan latar belakang di atas, dapat dirumuskan permasalahan sebagai berikut: 1) Bagaimana gambaran tentang pengembangan kapasitas kegiatan pembelajaran dengan menanamkan konsep keterampilan memberi, sehingga peserta didik memahami gaya hidup 
memberi; 2) Bagaimana gambaran tentang pengembangan kapasitas kegiatan pembelajaran dengan mempraktekkan keterampilan memberi sehingga peserta didik memiliki gaya hidup memberi dan 3) Dengan permasalahan yang dijelaskan sebelumnya dan rumusan masalah yang dibuat, serta mengacu pada referensi tentang keterampilan memberi, penulis memiliki gagasan untuk mengembangkan kapasitas kegiatan pembelajaran melalui keterampilan memberi, dengan tujuan: a) memberi gambaran tentang pengembangan kapasitas kegiatan pembelajaran dengan menanamkan konsep keterampilan memberi agar peserta didik memahami gaya hidup memberi dan $b$ ) memberi gambaran tentang pengembangan kapasitas kegiatan pembelajaran dengan mempraktekkan keterampilan memberi agar peserta didik memiliki gaya hidup memberi. Konsep memberi bisa diperkenalkan terlebih dahulu dalam mata pelajaran yang memungkinkan misalnya mata pelajaran bahasa, dengan cara mengintegrasikan tugas-tugas keterampilan memberi (Marzuki, 2012). Hal ini juga didukung oleh tulisan Miftah (2013) yang mengatakan bahwa pembelajaran ilmu sosial menjadi salah satu alternatif dalam upaya mengembangkan, membina karakter.

\section{KAJIAN LITERATUR DAN PEMBAHASAN Kajian Literatur Teori Belajar}

Belajar harus menimbulkan suatu perubahan (Ng, 2005a). karena tanpa adanya perubahan berarti, peserta didik hanya sebatas mempelajari teori. Teori, sebagus apapun, tidak dapat digunakan untuk menyelesaikan masalah jika tidak pernah dipraktekkan. Dalam belajar, mempraktekkan menjadi kata kunci untuk terjadinya suatu perubahan yang dapat menimbulkan kesuksesan. Supaya perubahan yang diharapkan terjadi, dalam mengajar seorang pendidik harus dapat menularkan tiga hal, yaitu learning skill, thinking skill, dan life skill (Ng, 2005b). Dengan mempelajari ketiga hal di atas diharapkan seorang peserta didik akan mengalami perubahan demi perubahan, dari yang tadinya kekanak-kanakan menjadi seorang yang matang, dan pada akhirnya menjadi seorang warga negara yang bisa berkontribusi terhadap negara, bukan yang merugikan negara. Dengan learning skill peserta didik diajar bagaimana mempelajari sesuatu secara efektif dan efisien sehingga dapat mencapai tujuan yang diharapkan. Sebagai contoh, ketika sudah mempelajari peta Jawa Tengah, maka bepergian dari Yogyakarta menuju Jakarta tidak lagi membingungkan karena peserta didik paham akan urut-urutan stasiun yang akan dilewati sebelum akhirnya sampai ke stasiun Gambir di Jakarta. Dengan thinking skill, peserta didik belajar bagaimana cara berpikir benar, yang dapat menunjang keberhasilan. Hal ini perlu dipelajari sungguh-sungguh karena keterampilan berpikir bukan keterampilan yang mudah dilakukan, karena jika mudah pasti banyak yang sudah melakukannya (Maxwell, 2009). Pada akhirnya, peserta didik juga perlu mengenal dan mempraktekkan life skill, misalnya tidak mudah menyerah, tidak mudah putus asa. Pada dasarnya, kegagalan bisa dihindari ketika sikap tidak mudah menyerah dipupuk terus. Bagi orang yang tidak mudah menyerah, kegagalan merupakan bahan bakar untuk tekat yang lebih besar dalam rangka mencapai keberhasilan di masa datang (Meyer, 2009). Sikap tidak mudah menyerah bisa dilatih, salah satunya adalah dengan mengelola perasaan. Perasaan itu sendiri bisa baik dan buruk, dan bersifat tidak stabil sehingga perlu dikelola (Meyer, 2011). Untuk mencapai ketiga hal dimaksud tidak mudah. Pendidik harus dapat mengelola kegiatan belajar sehingga peserta didik merasa senang dalam belajar. Pada umumnya, peserta didik dapat mempelajari sesuatu dengan cepat dan senang ketika apa yang dipelajari dapat digunakan untuk mencapai tujuan tertentu. Dengan mengetahui tujuan, kegiatan pembelajaran akan dilakukan dengan sungguh-sungguh ( $\mathrm{Ng}, 2005 \mathrm{~b})$. Pendidik memberitahu bahwa dengan mengenal dan mempraktekkan keterampilan memberi, diharapkan peserta didik akan menjadi orang yang 
terbiasa dengan keterampilan memberi untuk orang lain atau memiliki gaya hidup memberi dimanapun dan kapanpun. Kebiasaan memberi untuk orang lain akan membuat hidup menjadi lebih menyenangkan, dan pada akhirnya kualitas hidup juga meningkat. Jadi, dengan berlatih keterampilan memberi, peserta didik belajar meningkatkan kualitas hidup melalui tindakan nyata yang dilakukan selama kegiatan pembelajaran. Hal ini juga didukung oleh hasil penelitian tentang integrasi pendidikan karakter ke dalam satu mata kuliah yang dapat meningkatkan pemahaman mahasiswa terhadap nilai-nilai karakter (Suranto, 2014). Dalam hal ini dengan mengintegrasikan nilai memberi ke dalam pembelajaran, peserta didik menjadi lebih mengerti tentang apa itu memberi. Disamping itu, dengan berlatih memberi, berarti ada pendekatan pembelajaran yang sifatnya aktif. $\mathrm{Hal}$ ini sekaligus bisa untuk menanggapi hasil penelitian terhadap guru-guru pendidikan jasmani SMP di kota Yogyakarta dimana salah satu hasil penelitiannya menyebutkan bahwa praktek belajar mengajar pendidikan karakter masih cenderung bersifat internalisasi pasif (Dimyati. 2014).

\section{Kegiatan Pembelajaran}

Perubahan-perubahan dalam kehidupan terjadi begitu cepat dan pengetahuan yang ada juga menjadi cepat ketinggalan. Pengetahuan hari ini sudah dianggap tidak cocok lagi untuk hari esok ( $\mathrm{Ng}, 2005 \mathrm{a})$. Oleh karena itu, pendidikan perlu memberikan respon yang cepat terhadap hal seperti ini. Perubahan dalam pendidikan dilakukan supaya pendidikan bisa mengatasi berbagai tantangan yang terjadi di masyarakat dengan kompetensi-kompetensi yang relevan pada saat ini. Seberapa jauh sekolah mampu menghadapi tantangan sangat tergantung salah satunya pada kapasitas kegiatan belajar yang dilakukan (Ng, 2005a). Kegiatan belajar di sekolah menjadi hal penting yang dapat menentukan berhasil tidaknya sekolah dalam menjawab permasalahan dimaksud. Sekolah dapat memperbesar kapasitas kegiatan pembelajaran dengan berbagai terobosan. Setiap terobosan diajarkan dengan cara menanamkan konsep terlebih dahulu dan kemudian mempraktekkannya dalam kegiatan pembelajaran sehari-hari. Terobosan-terobosan ini merupakan suatu langkah yang ditawarkan untuk menjawab permasalahan yang berbedabeda. Pengembangan keterampilan memberi ditawarkan sebagai terobosan untuk ditanamkan dan dipraktekkan dalam kegiatan pembelajaran untuk menjawab permasalahan tentang sikap kurang peduli pada orang lain, yang berawal dari mind set yang salah. Dengan mengembangkan keterampilan memberi, peserta didik belajar untuk mengarahkan mind setnya sebagai seorang pemberi (a giver) dan kemudian mempraktekkan keterampilan memberi yang ada dalam pikirannya. Dengan demikian, sejak dari muda peserta didik dibiasakan menjadi seorang pemberi, dan bukan seorang pengambil ( $a$ taker). Untuk bisa memberi dengan cara dan maksud yang benar, harus dimulai dari pikiran terlebih dahulu. Diharapkan dengan mengenalkan dan mempraktekkan keterampilan memberi, peserta didik dapat menjadi seorang yang suka memberi dengan cara dan maksud yang benar sebagai-mana diungkapkan oleh Jamal dan Mc Kinnon (2009).

\section{Konsep Keterampilan memberi}

Konsep memberi menurut Maxwell (2009) bahwa seorang yang tidak egois memiliki pikiran bermurah hati pada orang lain dengan memberi sesuatu. Dengan memberi kualitas hidup meningkat. Dengan memberi diperoleh kebahagiaan dan kepuasan karena dapat memberikan sesuatu kepada orang lain yang sangat membutuhkan. Konsep memberi menurut Jamal dan Mc Kinnon (2009) meliputi: a) apa yang dapat diberikan; b) siapa yang harus diberi; dan c) bagaimana memberi dilakukan.

Memberi merupakan kebutuhan mendasar setiap manusia, yang dapat menguntungkan bagi pihak pemberi dan yang diberi (Jamal dan Mc. Kinnon, 2009). Disamping itu, memberi juga bisa menjadi sarana untuk meningkatkan komunikasi. 
Maxwell (2011) mengatakan bahwa setiap hari pada dasarnya orang selalu berkomunikasi, tetapi hanya sedikit yang 'connect'. Hal ini disebabkan prinsip connecting kurang diperhatikan. Salah satu prinsip tersebut mengatakan bahwa connecting adalah berbicara tentang apa yang menjadi kepentingan orang lain dan memberi merupakan salah satu keterampilan yang menyangkut kepentingan orang lain. Banyak orang mengaitkan memberi dengan uang. Karena sering dikaitkan dengan uang menjadikan orang tidak selalu mau melakukan kegiatan memberi dengan berbagai alasan, misalnya tidak mempunyai banyak uang, atau sedang memiliki banyak kebutuhan, sehingga tidak dapat melakukan kegiatan memberi. Memberi tidak selalu harus berupa uang. Jamal dan Mc Kinnon (2009) menyebutkan bahwa hal-hal yang dapat diberikan meliputi uang, waktu, keterampilan, perhatian, pengetahuan, nasehat, kepemimpinan, harapan, tawa, sentuhan, kehidupan, kesehatan, kasih sayang. Ketika akan melakukan keterampilan memberi, yang selalu ada di dalam pikiran untuk diberi sesuatu adalah orang. Hal ini tidak salah bahwa orang menjadi salah satu objek yang menerima pemberian. Akan tetapi orang di sini tidak selalu hanya diartikan orang lain saja. Jamal dan Mc Kinnon (2009) mengatakan bahwa melakukan keterampilan memberi dimulai dari yang paling dekat, yaitu memberi bagi diri sendiri terlebih dahulu. Sebagai contoh, keberhasilan setelah berjuang keras menyelesaikan suatu pekerjaan selama berminggu-minggu dapat dirayakan dengan memberi hadiah bagi diri sendiri. Memberi hadiah untuk diri sendiri setelah melakukan tugas berat dapat menjadi motivasi dan memberi energi untuk menyelesaikan tugas-tugas berikutnya (Meyer, 2010a). Jika tidak pernah memberikan hadiah pada diri sendiri, ada kecenderungan peserta didik akan mengalami kesulitan ketika harus memberikan hadiah kepada orang lain. Untuk itu, memberi hadiah pada diri sendiri juga perlu dilatih. Setelah memberi kepada diri sendiri, dilanjutkan dengan memberi kepada keluarga, dan kemudian kepada masyarakat. Hal ini dimaksudkan supaya jangan sampai keterampilan memberi dilakukan kepada yang jauh tetapi yang dekat diabaikan. Pada akhirnya, keterampilan memberi tidak hanya bisa dilakukan terhadap manusia saja, tetapi bisa juga terhadap bumi. Manusia perlu memberikan perhatian pada bumi yang ditinggali supaya kondisinya tidak mendatangkan bencana bagi manusia, misalnya mengurangi penggunaan peralatan yang dapat merusak lapisan ozon. Setelah melakukan kegiatan memberi, hal selanjutnya yang perlu diketahui dan diajarkan kepada peserta didik adalah bagaimana kegiatan keterampilan memberi harus dilakukan. Jamal dan Mc.Kinnon (2009) mengatakan bahwa memberi sebaiknya dilakukan sebagai berikut: 1) Memberi dilakukan dengan rasa hormat sehingga yang diberi merasa senang menerima pemberian tersebut; 2) Memberi juga harus dilakukan dengan kerendahan hati agar yang diberi tidak merasa sakit hati karena direndahkan; dan 3) Memberi harus dilakukan tanpa syarat sehingga yang diberi tidak merasa berhutang.

Dampak dari memberi yaitu dapat mengurangi keegoisan. Pelajar yang suka berkelahi bisa dikatakan egois, karena ada kecenderungan untuk memuaskan nafsu marah. Ketika seorang pelajar terbiasa dengan keterampilan memberi, misalnya memberi memberi maaf, maka ajakan untuk berkelahi tidak akan ditanggapi karena yang mengajak berkelahi sudah diberi maaf. Meskipun demikian, perkelahian hanya salah satu masalah yang diharapkan bisa dipecahkan dengan kebiasaan memberi. Masih banyak permasalahan di dunia yang bisa berkurang jika peserta didik memiliki kebiasaan memberi, seperti: banyaknya orang kelaparan, tidak memiliki air bersih, meninggal karena penyakit yang sebetulnya bisa dicegah, banyak penduduk dunia yang buta huruf. Jika ada lebih banyak peserta didik yang mau menabung sebagian dari uang saku dan memberikan kepada orang lain, maka akan lebih banyak orang kelaparan yang dapat ditolong. Demikian juga ketika ada lebih banyak peserta didik yang mau memberikan sebagian waktu bermain dengan gadget untuk 
mengunjungi kakek neneknya atau orang-orang jompo yang kesepian, maka akan lebih banyak orang-orang jompo yang terhibur dan lebih memiliki semangat hidup. Dari deskripsi tentang berbagai permasalahan di atas, semakin jelas dan nyata bahwa keterampilan memberi menjadi keterampilan yang sangat mungkin untuk mengurangi permasalahan yang ada di dunia ini. Pada akhirnya, hal yang perlu diketahui ketika mempraktekkan keterampilan memberi adalah bahwa dengan memberi sebenarnya peserta didik tidak kehilangan. Dengan memberi, akan diperoleh beberapa keuntungan, diantaranya: a) memiliki teman-teman baru; b) memiliki rasa aman; c) kesehatan yang stabil; d) kebahagiaan; dan e) rasa bangga.

Dari uraian di atas maka menjadi penting untuk membuat peserta didik belajar tentang keterampilan memberi. Terdapat dua gambaran tentang konsep keterampilan memberi. Pertama, Benjamin Franklin dalam Maxwell (2009) setiap bangun pagi selalu bertanya pada diri sendiri tentang kebaikan apa yang akan dilakukan bagi orang lain. Franklin memiliki mind set seorang giver, dan mind set seperti ini telah membuatnya memiliki gaya hidup memberi. Setiap hari selalu ada keinginan untuk melakukan keterampilan memberi bagi orang lain. Dari pertanyaan Franklin di atas tersirat beberapa pertanyaan lain, yaitu: a) siapa saja yang dapat diberi hari ini; b) di mana orang-orang tersebut dapat ditemui; c) pemberian apakah yang sebaiknya diberikan; dan d) dengan cara bagaimanakah pemberian itu mesti dilakukan supaya orangorang tersebut menerima dengan suka cita, tanpa ada beban.

Kedua, seorang pelukis yang tidak pernah mempraktekkan keterampilan yang dimiliki akan merasa kaku atau mengalami kesulitan ketika harus mempraktekannya kembali. Terampil akan sesuatu selalu diperoleh melalui latihan yang berulang-ulang. Demikian pula dengan keterampilan memberi. Memberi adalah salah satu dari keterampilan yang harus dilatihkan di sekolah secara berulang-ulang setiap hari supaya peserta didik terampil dalam memberi dan memiliki mind set seorang pemberi. Jika dilatih sejak masih muda, maka peserta didik akan menjadi terbiasa dengan keterampilan memberi. Untuk melengkapi konsep keterampilan memberi, disamping hal-hal di atas dapat dilatihkan juga dengan beberapa pertanyaan, seperti: 1) Kapan, memberi harus dilakukan pada saat yang tepat; 2) Mengapa, jawaban atas pertanyaan mengapa memberi dilakukan juga perlu untuk didiskusikan supaya peserta didik paham bahwa memberi harus dilakukan dengan maksud positif; dan 3) Seberapa banyak keterampilan memberi dapat dilakukan (Jamal dan Mc Kinnon, 2009).

Pada dasarnya, bagi yang sudah terampil dengan keterampilan memberi atau sudah memiliki mind set seorang giver, keterampilan memberi dapat dilakukan kapan saja dan dimana saja serta seberapapun yang sanggup diberikan. Bagi seorang giver, kesempatan untuk melakukan keterampilan memberi sangat mudah untuk ditemukan karena baginya hidup adalah untuk memberi. Seorang giver yang sudah terampil tidak akan cemas ketika melakukan kegiatan memberi, karena setiap hari harapan untuk selalu mendapatkan yang baik selalu ada dalam pikirannya. Hal ini sejalan dengan Meyer (2014) yang menekankan untuk selalu mengharapkan sesuatu yang baik setiap hari. Sebaliknya, bagi yang belum terampil, terlebih bagi seorang taker, kesempatan untuk memberi seperti tidak pernah dilihat karena fokus pikirannya berbeda, bukan pada memberi tetapi mengambil. Hal ini seperti yang dikatakan Osteen (2004) bahwa menjadi seorang giver sulit ketika mata tertuju pada diri sendiri. Sementara itu, sebenarnya keterampilan memberi dapat dipraktekkan setiap saat dan dimanapun. Setiap hari dan di manapun peserta didik berada, kesempatan memberi selalu ada. Diperlukan kejelian untuk mencari peluang. Seseorang tidak mungkin untuk memberikan sesuatu yang tidak dimilikinya. Hal ini sangat penting untuk disadari oleh pendidik. Ketika tidak pernah diperhatikan, maka akan sangat sulit bagi peserta didik untuk memberikan perhatian kepada orang lain. 
Demikian juga, ketika peserta didik tidak pernah diberi senyum, maka memberi senyum kepada orang lain akan menjadi hal yang sulit. Meskipun demikian, hal-hal tersebut bisa dilatihkan sehingga sekalipun belum pernah mendapatkan, tetapi jika dibekali dengan latihan yang sungguhsungguh, peserta didik yang jarang diberi senyum menjadi bisa memberi senyuman terlebih dahulu. Sebelum dilatih, peserta didik perlu diajak untuk senantiasa mendeklarasikan bahwa hidup mereka adalah hidup yang senantiasa diberi anugerah. Hal ini penting karena peserta didik tidak mungkin untuk mengharapkan menerima banyak anugerah jika yang diperkatakan setiap hari adalah soal kekurangan (Osteen, 2012). Untuk bisa memiliki keterampilan memberi, harus selalu ada keyakinan akan anugaerah yang senantiasa diterima setiap hari. Selanjutnya, keterampilan memberi akan lebih memberikan makna kepada peserta didik apabila pemberian yang dilakukan adalah pemberian yang berkualitas dengan tetap mempertimbangkan budaya yang berlaku, sebagaimana ditulis oleh Setiawan (2012) tentang kompetensi interkultural yang menjadi bekal untuk melakukan adaptasi dan komunikasi antarbudaya dengan tetap beridentitas dan berkarakter keindonesiaan.

Dari uraian di atas maka menjadi penting untuk membuat peserta didik belajar tentang keterampilan memberi.

\section{Pembahasan}

\section{Pengembangan Kapasitas Kegiatan Pembelajaran}

Perluasan kapasitas kegiatan pembelajaran tidak selalu berarti penambahan jam belajar, tetapi lebih kepada mengembangkan soft skill untuk membekali peserta didik di masa datang. Dengan bekal soft skill yang dipraktekkan setiap hari melalui tugas-tugas proyek sederhana, peserta didik diharapkan makin siap dan tangguh dalam menghadapi masalah sesungguhnya yang ditemukan di masyarakat. Hal ini didukung oleh hasil penelitian dari Mutaqin (2014) yang menyimpulkan bahwa kemampuan soft skill mahasiswa dapat ditingkatkan melalui pengembangan nilai-nilai karakter antara lain dalam disiplin, tanggung jawab, peduli. Disamping makin siap dan tangguh, peserta didik juga diharapkan dapat berperan dalam memberikan dampak positif bagi lingkungannya. Salah satu yang dapat dilatihkan adalah dengan membuat peserta didik mampu memimpin (Maxwell, 2013), paling tidak memimpin diri sendiri terlebih dahulu melalui praktek soft skill. Dengan mampu memimpin diri sendiri berarti mampu untuk mengendalikan diri, termasuk mengendalikan diri dalam mengambil keputusan-keputusan penting. Membuat keputusan merupakan salah satu dari dua hal kunci yang dapat membuat setiap hari menjadi hari yang berharga (Maxwel, 2004). Hal ini sangat penting untuk diperhatikan karena pada dasarnya hidup adalah $10 \%$ apa yang terjadi pada kita, sedangkan $90 \%$ adalah bagaimana kita merespon hal yang terjadi (Osteen, 2011). Dengan soft skill yang terlatih diharapkan peserta didik dapat mematahkan mentalitas 'sekedarnya' agar bisa menjadi yang terbaik, tidak sekedar menjadi pribadi yang ratarata atau biasa-biasa saja (Osteen, 2013).

Jika sekolah menginginkan supaya lulusannya memiliki kualitas seperti digambarkan di atas, maka keinginan tersebut harus direalisasikan dalam kegiatan pembelajaran setiap harinya, baik secara teori dalam arti penanaman konsep maupun praktek. Apa yang ditekuni setiap hari akan membentuk peserta didik (Meyer, 2013). Einstein dalam Maxwell (2014b) mengatakan bahwa sebaiknya berusahalah untuk menjadi orang yang memiliki nilai, bukan orang yang sukses, karena orang yang memiliki nilai pasti akan memiliki kualitas hidup lebih baik yang akan membawanya pada kesuksesan. Nilai di sini menunjuk pada suatu soft skill. Orang yang memiliki soft skill 'tidak mudah menyerah' akan cenderung memiliki kualitas hidup lebih baik karena memiliki daya juang yang tinggi. Soft skill adalah tingkah laku personal dan interpersonal yang dapat meningkatkan dan memaksimalkan kinerja seseorang dalam kehidupan sehari-hari (Widarto, 2012). Dalam 
pembahasan ini, kapasitas kegiatan pembelajaran diperluas dengan mengintegrasikan soft skill yang berasal dari konsep memberi, yang diharapkan dapat meningkatkan kepedulian. Pengintegrasian ini diwujudkan dalam bentuk tugas-tugas keterampilan memberi yang harus dilakukan oleh peserta didik, baik di dalam kelas maupun di dalam kehidupan sehari-hari di luar kelas. Kegiatan pembelajaran diarahkan agar peserta didik belajar teori dan praktek secara konsisten dan kontinyu, yaitu mempraktekkan nilai-nilai memberi yang dapat membentuk pribadi yang siap menyongsong masa depan dan memberi kontribusi bagi negara, melalui sikap suka memberi. Hal ini sejalan dengan tulisan Abduljabar (2014). yang mengatakan pendidikan karakter melalui aktivitas jasmani berbasis nilai dapat merupakan alternatif untuk mendidik karakter siswa. Dalam hal ini memberi merupakan aktivitas jasmani. Terkait dengan hal di atas, pendidik harus mendeskripsikan kegiatan pembelajaran secara jelas sehingga peserta didik memiliki gambaran tentang apa yang akan dilakukan, arah yang akan dituju, serta permasalahan yang dapat diselesaikan nantinya melalui praktek-praktek yang dilakukan setiap harinya dalam kegiatan belajar di sekolah. Secara ringkas, perluasan kapasitas kegiatan pembelajaran dengan konsep keterampilan memberi dilakukan dengan menanamkan konsep tersebut kepada peserta didik dan mempraktekkannya sesuai topik yang dipelajari.

\section{Pengembangan Konsep Keterampilan Memberi}

Seperti halnya dengan konsep pembelajaran holistik yang menginginkan peran peserta didik bergeser, dari pasif ke aktif, maka dalam kajian ini peran peserta didik juga dituntut aktif. Dalam pembelajaran holistik, peran pasif digambarkan sebagai sekedar menerima informasi, sedangkan peran aktif adalah sebagai orang yang mampu memecahkan masalah secara mandiri, berpikir kritis, serta kreatif dalam mengaplikasikan fakta, konsep, dan prinsip yang dipelajari (Widarto, 2012). Dalam kajian ini, peserta didik dilatih untuk secara aktif melakukan kegiatan memberi melalui tugas-tugas yang diberikan. Jadi, tugas-tugas yang diberikan harus bisa merangsang peserta didik untuk melakukan berbagai kegiatan memberi secara nyata, sebagaimana diungkapkan oleh Suwarna dan Jatirahayu (2013) bahwa guru adalah aktor terdepan yang secara langsung berhadapan dengan pembelajar untuk menyemaikan, membudayakan, dan membiasakan karakter sehingga terintenalisasi dalam diri pembelajar dan dipraktikkan dalam kehidupan nyata sehari-hari dan akhirnya menjadi watak atau kepribadian luhur pembelajar. Untuk mengembangkan konsep keterampilan memberi agar lebih berkualitas, ada beberapa hal yang dapat dilakukan.

Pertama, keterampilan memberi dilakukan terhadap orang-orang yang tidak mungkin untuk membalas pemberian tersebut. Dengan memberi kepada orang yang tidak dapat membalas, maka pemberian tersebut akan menjadi pemberian yang tulus karena yang memberi tidak mengharapkan apapun.

Kedua, keterampilan memberi tetap dilakukan sekalipun peserta didik, sebagai orang yang memberi, tidak memiliki banyak. Contoh peserta didik $A$ adalah tipe orang yang tidak pandai bicara, tetapi diminta untuk memberikan kata-kata positif kepada peserta didik lainnya yang sedang sedih. Dalam hal ini pendidik mengajarkan bahwa yang memberi tidak harus orang yang memiliki banyak.

Ketiga, mempraktekkan an extraordinary giving skill. Keterampilan memberi dilakukan dengan cara yang luar biasa, yaitu, a) dari segi kuantitias yang diberikan, contoh, berilah dua kilogram gula pasir, jika ada yang memerlukan satu kilogram; dan b) cara memberikan, contoh: tetap mencoba untuk memberikan bantuan dengan tulus, sekali pun pada saat yang sama ada urusan lain yang harus dikerjakan. Yang harus ditanamkan kepada peserta didik adalah sama-sama memberikan bantuan, tetapi jika yang satu dilakukan secara tulus, sedangkan lainnya dilakukan dengan mengomel dalam hati dan kemudian membicarakan tentang keter- 
paksaan ini kepada orang lain hasilnya akan berbeda; dan c) waktu yang dibutuhkan, contoh, jika ada yang ingin menceritakan permasalahan secara singkat karena takut menyita banyak waktu, berikan waktu yang secukupnya sampai yang bersangkutan merasa lega.

Hal lain yang dapat dilakukan untuk mengembangkan keterampilan memberi adalah dengan menetapkan indikator dari suatu tugas memberi. Dengan menetapkan indikator, peserta didik diharapkan akan melakukan keterampilan memberi beberapa kali sampai indikator yang ditetapkan tercapai. Meskipun demikian, tidak semua indikator dapat langsung dicapai. Ada beberapa indikator yang memerlukan waktu panjang untuk mencapaiknya. Berikut adalah beberapa contoh indikator dari suatu objek pemberian yang dilakukan di dalam kelas. Pendidik dan peserta didik dapat mengembangkannya lebih banyak lagi.

Dengan mengembangkan keterampilan memberi sebagaimana contoh-contoh di atas, maka pemberian yang dilakukan akan semakin berkualitas dan peserta didik akan memiliki kehidupan yang lebih berkualitas juga. Selanjutnya, untuk memperluas kapasitas kegiatan pembelajaran, setelah mempraktekkan di dalam kelas, peserta didik juga diminta untuk mempraktekkan di luar kelas kepada orangorang yang benar-benar membutuhkan. Tabel 1 adalah beberapa contoh indikator dari suatu objek pemberikan yang dilakukan di luar kelas.

\section{Penerapan Keterampilan Memberi dalam Pembelajaran}

Untuk dapat menjadi sukses, gaya hidup yang benar harus dimiliki. Demikian juga untuk dapat memiliki hidup yang menyenangkan, peserta didik harus menjadikan keterampilan memberi sebagai salah satu gaya hidup yang harus dimiliki. Salah satu cara untuk menjadikan keterampilan memberi menjadi gaya hidup adalah dengan mengelola perasaan dan bukan mengikutinya, karena perasaan tidak selalu benar. Untuk itu, perlu latihan dengan penekanan pada gaya hidup yang tetap memilih melakukan hal benar, bagaimanapun perasaan yang dimiliki saat melakukan (Meyer, 2008). Dengan menjadikan keterampilan memberi sebagai gaya hidup sejak dari kecil, diharapkan ketika dewasa dan bekerja, peserta didik dapat lebih menjaga diri untuk tidak melakukan tindakan negatif, karena mind set sudah dilatih untuk diarahkan menjadi seorang giver, bukan seorang taker. Tahapan penerapan keterampilan memberi dalam pembelajaran adalah sebagai berikut.

Tabel 1 Contoh indikator dari suatu objek pemberian yang dilakukan di dalam kelas

\begin{tabular}{ll}
\hline \multicolumn{1}{c}{ Objek Pemberian } & \multicolumn{1}{c}{ Indikator } \\
\hline Memberi pada Orang lain: & \\
\hline $\begin{array}{l}\text { Memberi kata-kata positif ketika } \\
\text { ada teman yang memberi jawaban } \\
\text { salah atas pertanyaan yang } \\
\text { diberikan oleh pendidik di dalam } \\
\text { kelas }\end{array}$ & $\begin{array}{l}\text { Teman yang menjawab salah } \\
\text { merasa tidak malu dan mau } \\
\text { mencoba lagi. }\end{array}$ \\
$\begin{array}{l}\text { Memberikan penjelasan ketika ada } \\
\text { teman yang tidak paham setelah }\end{array}$ & $\begin{array}{l}\text { Teman yang tadinya masih } \\
\text { pendidik menjelaskan suatu } \\
\text { materi. }\end{array}$ \\
$\begin{array}{l}\text { Memberi informasi kepada teman } \\
\text { yang tidak masuk tentang peker- } \\
\text { jaan rumah yang harus dikum- } \\
\text { pulkan pada pertemuan berikut- }\end{array}$ & $\begin{array}{l}\text { Teman yang tidak masuk kelas } \\
\text { dumah pada pertemuan selan- } \\
\text { nya. }\end{array}$ \\
$\begin{array}{l}\text { jutnya, karena ada teman yang } \\
\text { peduli untuk memberikan infor- }\end{array}$ \\
\hline
\end{tabular}


Tabel 2 Contoh Indikator dari Suatu Objek Pemberian yang Dilakukan di luar Kelas

\begin{tabular}{|c|c|}
\hline Objek Pemberian & Indikator \\
\hline \multicolumn{2}{|l|}{ Memberi Diri Sendiri } \\
\hline $\begin{array}{l}\text { Memberi hadiah pada diri sendiri } \\
\text { setelah melakukan kerja keras }\end{array}$ & $\begin{array}{l}\text { Timbul motivasi dan semangat baru } \\
\text { untuk melanjutkan }\end{array}$ \\
\hline $\begin{array}{l}\text { Memberi diri sendiri istirahat yang } \\
\text { cukup }\end{array}$ & Badan terasa lebih segar \\
\hline $\begin{array}{l}\text { Memberi tubuh lebih banyak maka- } \\
\text { nan yang sehat dari pada yang tidak } \\
\text { sehat }\end{array}$ & Pembelian junk-food dikurangi \\
\hline \multicolumn{2}{|l|}{ Memberi pada orang lain: } \\
\hline $\begin{array}{l}\text { Memberi pada orang lain yang } \\
\text { membutuhkan }\end{array}$ & Merasa tersentuh \\
\hline $\begin{array}{l}\text { Memberi pada orang lain yang } \\
\text { tersisih }\end{array}$ & $\begin{array}{l}\text { Merasa hidup kembali, karena ada } \\
\text { orang yang memperhatikan }\end{array}$ \\
\hline $\begin{array}{l}\text { Memberi pertolongan pada orang } \\
\text { yang suka menjelek-jelekkan }\end{array}$ & $\begin{array}{l}\text { Timbul rasa bersalah dan malu } \\
\text { karena yang membantu adalah } \\
\text { orang yang selama ini dijelek- } \\
\text { jelekkan. }\end{array}$ \\
\hline $\begin{array}{l}\text { Memberi doa pada orang yang } \\
\text { dibenci }\end{array}$ & Kebencian menjadi berkurang \\
\hline $\begin{array}{l}\text { Membantu orang-orang yang sudah } \\
\text { tua dan perlu bantuan dalam } \\
\text { menyeberang jalan }\end{array}$ & $\begin{array}{l}\text { Ada ucapan terima kasih yang } \\
\text { mendalam dari orang yang } \\
\text { diseberangkan. }\end{array}$ \\
\hline \multicolumn{2}{|l|}{ Memberi pada benda: } \\
\hline $\begin{array}{l}\text { Memberi perhatian pada motor } \\
\text { dengan membersihkannya setiap } \\
\text { hari }\end{array}$ & Motor selalu kelihatan bersih \\
\hline $\begin{array}{l}\text { Memberi perhatian pada ruang } \\
\text { belajar dengan mengatur buku-buku }\end{array}$ & Rak buku tertata rapi \\
\hline
\end{tabular}

\section{Tahap Awal Kegiatan Pembelajaran}

Setiawan (2013) dalam tulisannya yang berjudul 'Peran Pendidikan Karakter dalam Mengembangkan Kecerdasan Moral mengemukakan suatu desain pendidikan karakter yang diawali dengan moral conditioning dan dilanjutkan dengan moral training. Berdasarkan tulisan tersebut berikut adalah beberapa hal yang dapat dilakukan pendidik pada tahap awal pembelajaran terkait dengan konsep keterampilan memberi: 1) Pendidik secara singkat dan dengan bahasa sederhana menjelaskan konsep keterampilan memberi atau bisa juga diberi teks singkat tentang memberi sebagaimana diungkapkan oleh Ningrum (2012) tentang mengajar membaca dengan tema membangun karakter; 2) Pendidik juga memberikan alasan mengapa diajarkan keterampilan memberi. Dengan mengetahui alasannya, peserta didik diharapkan akan lebih mantap dalam mempraktekkannya; 3) Untuk memperjelas konsep, pendidik memberikan contoh, misalnya: banyak orang yang mau mendengarkan dengan sungguh-sungguh ketika ada orang lain yang minta didengarkan. Dengan mengajarkan keterampilan memberi, peserta didik diajak untuk menyelesaikan masalah tersebut dengan memberi telinga untuk mendengarkan secara sungguh-sungguh; dan 4) Pendidik memberikan pengalaman-pengalaman nyata pada saat mempraktekkan keterampilan memberi, contoh: merasa hampir putus asa ketika mengalami kegagalan praktek berkali-kali, tetapi kemudian bangkit kembali sampai akhirnya berhasil walaupun baru beberapa kali. 


\section{Tahap Mengajar}

Setelah selesai dengan tahap awal, pendidik melanjutkan ke tahap berikutnya, yaitu mengajar bahasa Inggris sesuai topik, contoh: Feeling. Pendidik mengajarkan topik Feeling sebagaimana mengajarkan bahasa Inggris pada umumnya, bedanya pada tugas yang diberikan. Tugas mengandung penerapan keterampilan memberi dan harus dipraktekkan di dalam kelas dan juga di dalam kehidupan sehari-hari di luar kelas.

Contoh tugas I, variasi 1: keterampilan memberi yang dapat diintegrasikan dengan topic feeling: memberi dengan kata-kata positif secara lisan. Peserta didik diminta untuk membuat sebuah proyek dengan cara menggambar tangan atau menggunting gambargambar berdasarkan perasaan masing-masing peserta didik saat itu. Kemudian pada saat proyek dipresentasikan, setiap peserta didik diminta untuk berlatih memberikan komentar yang sifatnya memotivasi terkait dengan daya tarik atau kualitas proyek yang dipresentasikan. Demikian seterusnya sampai setiap peserta didik mempresentasikan proyeknya. Dalam hal ini, melalui kegiatan presentasi, peserta didik diajari untuk mempraktekkan keterampilan memberi dengan kata-kata positif. Tekanannya adalah melatih keterampilan memberi dengan kata-kata positif, bukan sekedar mengomentari suatu karya atau proyek.

Contoh tugas I, variasi 2: keterampilan memberi yang dapat diintegrasikan dengan topic feeling: memberi dengan kata-kata positif secara tertulis. Pendidik dapat juga mengumpulkan semua proyek tadi dan kemudian membaginya secara acak kepada peserta didik. Kemudian, peserta didik diminta untuk memberikan komentar tertulis terkait proyek tersebut. Pendidik memberikan rambu-rambu supaya peserta didik menuliskan kata-kata yang bersifat membangun dan memberikan kata-kata tertulis tersebut dengan tulisan yang rapi. Di sini peserta didik diarahkan untuk belajar mempraktekkan keterampilan memberi dengan kata-kata positif yang ditulis secara rapi. Hal ini penting untuk dilatihkan supaya peserta didik tidak membiasakan diri memberi kata-kata yang sifatnya destruktif.

Contoh tugas II: Memberi berita positif. Masih pada topik Feeling, peserta didik diminta menjadi seorang wartawan untuk mencari berita di sekeliling sekolah atau sekeliling rumah. Berita yang harus dikumpulkan adalah berita positif, berita yang memotivasi. Di sini peserta didik belajar untuk mencari berita positif di antara banyaknya berita negatif yang ada (selective hearing). Berita positif tersebut kemudian diberikan kepada peserta didik lainnya sehingga ketika mendengar berita tersebut, mereka akan menjadi bangkit semangatnya. Dalam contoh terakhir tekanan kegiatan belajar adalah pada melatih keterampilan memberi berita positif, bukan memberi gosip. Contoh di atas merupakan beberapa contoh pengembangan keterampilan memberi secara sederhana. Supaya peserta didik terbiasa dengan konsep memberi, maka pada setiap tugas yang diberikan keterampilan memberi perlu dimasukkan, disesuaikan dengan topic. Dengan kata lain, melalui contoh kegiatan pembelajaran bahasa Inggris di kelas dengan topik Feeling, keterampilan memberi yang diberikan adalah memberi kata-kata positif melalui komentar yang diberikan baik secara lisan maupun tulisan dan memberi berita positif untuk menumbuhkan semangat.

\section{Tahap Akhir Kegiatan Pembelajaran}

Pendidik menanyakan apakah melalui kegiatan praktek memberi tersebut peserta didik sudah benar-benar merasa melakukan kegiatan memberi. Jika rata-rata peserta didik menjawab sudah, maka pendidik bisa menanyakan lebih lanjut tentang perasaan mereka setelah dapat memberi sesuatu kepada orang lain. Tetapi jika ternyata rata-rata peserta didik menjawab belum, maka apabila waktu masih tersedia pendidik dapat menjelaskan kembali tentang konsep memberi kemudian dihubungkan dengan kegiatan praktek keterampilan memberi yang pada pembahasan kali ini berupa memberi katakata positif dan memberi berita positif. Akan tetapi jika waktu sudah habis, maka penjelasan 
tentang konsep memberi dapat dilakukan kembali pada pertemuan berikutnya. Agar praktek keterampilan memberi dapat lebih berarti bagi peserta didik, maka praktek dalam contoh di atas dapat dikembangkan lagi seperti berikut. 1) Peserta didik diminta kembali untuk memberi dengan kata-kata positif secara lisan, memberi tulisan dengan kata-kata positif, serta memberi berita positif yang diberikan kepada orang lain di masyarakat; dan 2) Peserta didik diminta untuk melakukan tiga atau beberapa kegiatan keterampilan memberi secara ekstra, misalnya mencari orang-orang yang tersisih dan kemudian mempraktekkan keterampilan memberi dengan cara memberi ucapan selamat pagi, selamat siang, atau selamat sore, atau ucapan selamat ulang tahun, jika kebetulan peserta didik mengetahuinya. Kemudian pada saat presentasi di dalam kelas, peserta didik memberikan penjelasan singkat alasan memilih tiga atau beberapa keterampilan memberi ekstra tersebut. Demikian seterusnya, setiap topik diberi tugastugas keterampilan memberi dengan jenis yang berbeda sebagaimana dikemukan oleh Jamal dan Mc. Kinnon. Pendidik juga bisa mengembangkan sendiri di luar jenis-jenis pemberian yang ditulis oleh Jamal dan Mc. Kinnon (2009).

Sebagai proyek akhir semester, pendidik bisa meminta kepada peserta didik untuk selama satu minggu mempraktekkan keterampilan memberi dengan melakukan tiga atau lebih kegiatan memberi per hari. Dengan melakukan kegiatan memberi selama satu semester, diharapkan peserta didik dapat memahami konsep keterampilan memberi melalui kegiatan praktek yang dilakukan. Pada akhirnya, uraian tentang perluasan kapasitas pembelajaran dengan keterampilan memberi dapat diringkas menjadi dua hal, yaitu: 1) Menanamkan konsep keterampilan memberi menjadi saat dimana peserta didik diarahkan untuk memahami mind set seorang giver; dan 2) Mempraktekkan keterampilan memberi menjadi saat dimana peserta didik belajar memiliki gaya hidup seorang pemberi melalui kegiatan memberi yang dilakukan secara nyata. Dengan demikian, perluasan kapasitas pembelajaran yang dilakukan harus benar-benar membuat kesadaran peserta didik tumbuh dalam proses menjadi seorang giver bukan seorang taker.

\section{SIMPULAN DAN SARAN}

\section{Simpulan}

Waktu keberadaan peserta didik selama beberapa tahun di sekolah harus menjadi waktu yang mengarahkan peserta didik menjadi pribadipribadi yang siap untuk masa depannya dan juga siap untuk memberikan kontribusi dalam memecahkan masalah yang ada di masyarakat. Dengan pengembangan keterampilan memberi diharapkan cara berpikir peserta didik dapat diarahkan untuk menjadi seorang giver melalui penanaman konsep keterampilan memberi dan kemudian mempraktekkannya untuk memberikan pengalaman nyata menjadi seorang giver, melalui latihan-latihan keterampilan memberi yang diberikan sesuai topik, tugas-tugas dan juga melalui proyek akhir semester. Dengan demikian, dapat disimpulkan bahwa: 1) Perluasan kapasitas kegiatan pembelajaran dengan mengembang kan keterampilan memberi pada peserta didik adalah untuk menanamkan konsep memberi dan memahami gaya hidup member; dan 2) Perluasan kapasitas kegiatan pembelajaran dengan mengembangkan keterampilan memberi pada peserta didik adalah dengan mempraktekkan keterampilan memberi dan membiasakannya menjadi gaya hidup memberi. Dengan dikenalkannya konsep memberi dan mempraktekkannya secara nyata sejak peserta didik masih muda diharapkan akan membuat mereka benar-benar memiliki gaya hidup memberi, karena mind set mereka sudah dibentuk untuk menjadi seorang giver, bukan seorang taker.

\section{Saran}

Terkait dengan pentingnya keterampilan memberi dan dampak positif yang dapat ditimbulkan, berikut adalah beberapa hal yang dapat disarankan oleh penulis. Pertama, Pendidik disarankan untuk mencoba mengintegrasikan 
keterampilan memberi dalam mata pelajaran yang diampunya. Dengan mencoba, pemahaman akan konsep dan praktek keterampilan memberi akan bertambah. Kedua, Pendidik perlu memberikan penekanan pada aktivitas praktek keterampilana memberi secara berulang-ulang. Dalam contoh di atas, peserta didik tidak sekedar memberi komentar atas suatu presentasi yang mungkin sudah biasa dilakukan. Kegiatan tersebut menekankan bahwa peserta didik sedang melakukan salah satu kegiatan berlatih keterampilan memberi kepada orang lain dengan kata-kata positif. Keterampilan memberi merupakan keterampilan yang sangat dibutuhkan saat ini. Oleh karena itu, pendidik harus ikut mempraktekkannya secara nyata dalam kehidupan sehari-hari, termasuk pada saat mengajar. Ketika diadakan review bersama, peserta didik dan pendidik saling membagikan pengalamannya dalam berlatih menjadi seorang giver.

\section{PUSTAKA ACUAN}

Abduljabar, B. 2014. Memperkokoh Pendidikan Karakter melalui Mediasi Aktivitas Jasmani Berbasis Nilai. Jurnal Pendidikan Karakter, Februari 2014, IV(3).

Dimyati. 2014. Kemampuan Guru Pendidikan Jasmani dalam Menyusun Rencana dan Praktik Pembelajaran Bervisi Karakter. Jurnal Pendidikan Karakter, Oktober 2014, IV(3).

Jamal, A \& Mc. Kinnon, H. 2009. The Power of Giving. New York: Penguin Group.

Kementerian Pendidikan dan Kebudayaan. 2013. Pengembangan Kurikulum 2013. Jakarta.

Marzuki. 2012. Pengintegrasian Pendidikan Karakter dalam Pembelajaran di Sekolah. Jurnal Pendidikan Karakter. Februari 2012, II(1).

Maxwell, J. 2009. How Successful People Think. New York: Hatchette Book Group.

Maxwell, 2010. Everyone Communicates, Few Connect. Nashville: Thomas Nelson.

Maxwell, J. 2013. How Successful People Lead. New York: Hatchette Book Group

Maxwell, J. 2014a. How Successful People Grow. New York: Hatchette Book Group

Maxwell, J. 2014b. Buat Hari ini Bermakna (Terj. Marlene T). Jakarta: MIC Publishing

Meyer, Joyce. 1995. Battlefield of the Mind. New York: FaithWords

Meyer, Joyce. 2008. Start Your New Life Today. New York: FaithWords

Meyer, J. 2009. Never Give Up. New York: Faith Words.

Meyer, J. 2010a. Eat the Cookies, Buy the Shoes. New York: Faithwords.

Meyer, J. 2010b. Power Thought. New York: Faithwords, Hatchette Book Group.

Meyer, J. 2011. Living beyond Your Feeling. New York: Faith Words.

Meyer, J. 2013. Making Good Habits. New York: Faith Words, Hatchette Book Group.

Meyer, J. 2014. Get Your Hopes Up. New York: Faith Words, Hatchette Book Group.

Miftah, M.2013. Pengembangan Karakter Anak melalui Pembelajaran IImu sosial. Jurnal Pendidikan Karakter. Juni 2013, III(2).

Mutaqin. 2014. Implementasi Pendidikan Karakter dalam Pembelajaran Berbasis Projek untuk Meningkatkan Soft Skill Mahasiswa. Jurnal Pendidikan Karakter, Juni 2014, IV(3).

$\mathrm{Ng}$, Pak Tee. 2005a. The Learning School. Singapore: Pearson.

Ng, Pak Tee. 2005b. Grow Me. Singapore: Pearson.

Ningrum, A. S. B. 2012. Teaching Extensive Reading Program with Character Building Theme: 
from zero to hero. Jurnal Pendidikan Karakter. Februari 2012, II(3).

Osteen, J. 2011. Everyday a Friday. New York: Faith Words.

Osteen, J. 2012. I Declare. New York: Hatchette Book Group.

Osteen, John. 2013. Living in the Abundance of God. New York: Faith Words.

Setiawan, A. K. 2012. Integrasi Pendidikan Karakter dalam Pembelajaran Berbasis Interkkultural. Jurnal Pendidikan Karakter. Oktober 2011, I(1).

Setiawan, D. 2013. Peran Pendidikan Karakter dalam Mengembangan Kecerdasan Moral. Jurnal Pendidikan Karakter. Februari 2013, III(1).

Sindo. 26 April 2011. Liputan Khusus Pendidikan.

Suranto, AW. 2014. Integrasi Pendidikan Karakter dalam Pembelajaran Mata Kuliah Komunikasi Interpersonal. Jurnal Pendidikan Karakter, Oktober 2014, IV(3).

Suwarna \& Jatirahayu, W. 2013. Pembelajaran Karakter yang Menyenangkan. Jurnal Pendidikan Karakter. Oktober 2013, III(3).

Widarto. 2012. Model Pembelajaran Soft Skill pada Pendidikan Vokasi Bidang Manufacture. Disertasi. Yogyakarta: Program Pasca Sarjana, Universitas Negeri Yogyakarta, tidak dipublikassikan. 